\title{
MALNUTRITION
}

$\mathrm{O}^{\mathrm{s}}$ N March 18, the Nutrition Society held, at the London School of Hygiene and Tropical Medicine, a symposium on "The Place of Food Science and Technology in the Campaign against Malnutrition". The symposium was primarily concerned with malnutrition in the under-developed countries, and in particular with malnutrition in children in the 'toddler' stage.

There is much evidence that malnutrition associated with lack of protein and calories is common in countries in which supplies of foods of animal origin, especially animal milk, are low; it is, in fact, the most common of all food deficiency states in the world as a whole. Its manifestations range from retardation in growth to serious disease and death. The West African word 'kwashiorkor' is now widely used to describe a form of the disease, with characteristic signs, occurring in children whose diet is grossly deficient in protein and less deficient in calories. The wider term 'protein-calorie malnutrition', covering the effects of both lack of calories and lack of protein, usually found together in the victims, is preferred by many workers, but it should be added that at present there is some confusion with respect to nomenclature.

As the result of intensive research during the past ten years in many parts of the world, the factors underlying protein-calorie malnutrition-dietary, agronomic, economic and social-are now well understood, but relatively little progress has as yet been made in prevention. Through food sciencemeaning in this context the study of foods and food values in relation to requirements-appropriate measures for correcting deficiencies can be demonstrated, and food technology, wisely applied, can increase supplies of nutritious foods pending, and in association with, the expansion of food production.

The symposium began with five papers, under the heading of "Problems and Some Solutions", given by workers from India (Dr. K. K. Halder), Turkey (Dr. O. Köksal), Iraq (W. Frankul), Pakistan (S. M. Ali) and Ghana (R. Orra ca-Tetteh) respectively, who are engaged in research at the Human Nutrition Research Unit at Mill Hill, under the direction of Prof. B. S. Platt. Each speaker outlined the background of the problem in his country and described some locally feasible method or methods, based on recent research, of making diets more satisfactory. These papers brought out on one hand the basic similarity of the situation in various parts of the world, and on the other, the differences from country to country which call for a local approach in applying food science and technology effectively. In introducing these contributions, Prof. Platt commented on the value of providing postgraduate experience in nutrition research and its application to workers from countries in which there are serious problems of nutrition and $a$ shortage of trained personnel to deal with them.

A paper on "Some African Problems" by Dr. F. Aylward (Department of Chemistry and Food Technology, Borough Polytechnic, London) reflected the author's experience as adviser to the Ministry of
Agriculture in Ghana in the capacity of a technical assistance expert for the Food and Agriculture Organization. $\mathrm{H}_{\theta}$ analysed the contributions which food technology can make in increasing supplies of nutritious foods available for consumption, suggesting various categories into which these contributions can be grouped. His paper was concerned with the application of food technology in ways which do not demand big capital outlay, rather than with the development of large-scale food industry. He considered that under African conditions there is an important place for small food-processing plants in rural areas, with low maintenance costs and minimum rəquirements for technical supervision. Dr. J. W. Corran (J. and J. Colman, Ltd., Carrow Works, Norwich), who dealt with "Factors Affecting De. velopment of Food Science and Technology and Food Resources in Pakistan", also drew on experience gained during a Food and Agriculture Organization assignment as a technical assistance expert. He directed attention to the lack of accurate data about food consumption and state of nutrition and of reliable agricultural statistics, which handicapped attempts to formulate and execute programmes to develop food production and food technology. For example, there were widely conflicting estimates of supplies of fish, an important food in East Pakistan. While Pakistan greatly needed trained food scientists and technologists, the number of active workers in these fields could at present be counted on the fingers of one hand. Facilities for training such workers in Pakistan did not exist, and even those available in the United Kingdom were far from satisfactory. Pakistan urgently needed the help of food technologists from abroad to foster the growth of food industry.

Dr. E. Wokes (Vegetarian Nutritional Research Centre, Research Laboratory, Stanborough School, Watford, Herts) discussed "India's Food Problems" on the premise that substantial increase in supplies of animal protein could not be expected in the foreseeable future. Attention must therefore be focused on plant proteins, which are cheaper than animal proteins, and may be obtained from pulses, groundnut preparations, leaf protein concentrates, and other sources. The lack of vitamin $B_{12}$ in plant proteins might be corrected by fortification with the synthetic vitamin itself. $\mathrm{He}$ referred to deficiencies of lysine and methionine in average Indian diets and to possibilities of making these good by suitable combinations of vegetable foods. In conclusion, he stressed the need for more clinical and nutritional research, and for developments in food technology, food control, agriculture, transport and education.

An account was given by Dr. W. F. J. Cuthbertson (Glaxo Laboratories, Ltd., Greenford, Middlesex) of 'The Commercial Development of 'Amama', a protein-rich Supplement in Nigeria". This preparation, based on groundnut flour to which casein, yeast, minerals and vitamins are added, is manufactured in a factory near Lagos. Tests made in Nigeria, where protein malnutrition is common, showed that 'Amama' was as effective in treating malnourished children as skim milk powder. Cuthbertson emphas- 
ized that the manufacture and distribution of a new food to wholesalers and retailers were not enough to ensure its use; an advertising and educational programme was essential so that the public can become aware of its availability and how to use it. He outlined the methods followed in promoting the sale of 'Amama', and the difficulties encountered.

Throughout the symposium there were many references to the need for popular education in nutrition, which must accompany all other measures to eliminate malnutrition. The last paper, by Dr. A. T. M. Wilson (Unilever House, Blackfriars, London), on "Nutritional Change; Some Comments from Social Research", dealt mainly with this subject. $\mathrm{He}$ quoted effectively a passage in a World Health Organization roport about the "baffling maze of tradition, taboo and magic, and the whole system of belief of the people about health and the causes of disease" of which educators must be aware. "In the past", the World Health Organization report continued, "most workers have tried, by repeated blows of didactic teaching, to hammer their way through the maze and break down the resistance to unaccustomed foods and eating practices-with very little success . . . because beliefs about food are part of the whole fabric of the life of a people". It follows that the social and psychological aspects of the campaign against malnutrition are of essential importance, an example being the complex social factors which influence lactation and weaning. Wilson also commented that the campaign called for co-operation between different disciplines and services, always difficult to secure. The epigram "God has not seen fit to divide our problems into the same categories as university chairs" was highly applicable to the problem of nutrition.

The papers and discussions at the symposium gave at least some answers to the questions implied in its title. While the general attitude was optimistic, the speakers recognized that immediate and facile solutions cannot be expected. There was emphasis on the need for action based on research and on an understanding of the complex factors which cause malnutrition.
W. R. AYkroyd

\section{GROWTH AND GENETICS OF HIGHER FUNGI}

$\mathrm{T}$

HE higher fungi commonly known as mushrooms, toadstools and bracket fungi and classified in the Basidiomycetes, have certain distinctive biological features which make them a favourable group in which to study their physiology of growth and their genetics. The large fruiting body with its size, shape and form, and in many species with its extraordinary rate of growth, offer's opportunities for studying the factors affecting growth, translocation and morphogenesis. The mycelium with its regular growth-pattern, its production of asexual spores and its ability to grow on simple minimal medium has all the properties of mycelia in other groups of lower fungi. The regular formation of a stable dikaryon from the compatible mating of monokaryons provides a system for studying gene action which is intermediate between the regular haploid-diploid cycle of yeast and the variable heterokaryon and homokaryon in Neurospora and Aspergillus. The complex mating system in the higher fungi, although it can be compared in its genetics with certain incompatibility systems in higher plants, has features that are not found in any other group of plants.

In a symposium organized by the British Mycological Society, under the chairmanship of its president, Miss G. M. Waterhouse, five aspects of the higher fungi were examined: (1) the effects of light and gravity on the growth and form of a fruiting body; (2) the factors, both internal and external to the hyphæ, which govern the regular pattern of growth and branching of the mycelium; (3) the extent of gene action and the transport of exogenous sub. stances along the hyphr; (4) the genetic and possible biochemical control of the complex mating system; (5) the mosaic structure of populations and sterility barriers in higher fungi.

Dr. B. E. Plunkett (Birkbeck College, London), using the fruiting-bodies of Polyporus brumalis, demonstrated components of the complex system of stimuli that operate to keep the cap horizontal and to ensure the production of spores on the lower side.
These are factors of importance if the fungus is to distribute its spores efficiently. The stalk of the young fruiting body, before the cap has expanded, grows towards a laterally placed light, but as the cap expands it is no longer attracted to the light but grows upwards under the influence of gravity on the horizontal stem. Light of low intensity obtained by shading the young stem with an artificial cap resulted in upward growth due to gravity. This showed that the geotropic response was present in the early as well as in the later stages of development. The weaker geotropic response is at first overruled by the strong photo-response, but later, as the percoptive region is shaded by the expanding cap, the geotropic response expresses itself. Rotation-with-light experiments demonstrated that the spore-bearing region develops away from the light and the cap develops at right angles to the incident light. These interesting studies in growth and morphogenesis were paraphrased by the statement that according to Corner the cap was an umbrella to keep rain from the spores, but now it could also be a parasol.

Turning from the fruit body to the mycelium, Dr. G. M. Butler (Birmingham) discussed the problems of the hyphal branching system in Coprinus dissemin. atus. Three types of hyphæe could be distinguished, main, primary branch and secondary branch. In Petri dish cultures the main hyphæ had the highest extension-rate and the greatest diameter, the secondary branch had the lowest rate and diameter. The monopoidal bianching system and the radial growth of a colony depend on these differential extension-rates of leading and branch hyphæ. A steady rate of growth of a whole branch system is maintained, from which it is concluded that the hyphal tip, the region where extension occurs, is not autonomous but is subject to competition and interaction occurring within the hyphal system. Experiments with two cultures separated by 'Cellophane' and growing out of step showed that under certain conditions there existed hyphal competition or 